Economic and Environmental Geology

Research Paper

\title{
Evaluation of Stability and Deterioration Characteristics for the Rock-carved Standing Buddha Triad in Gyeongju Seoak-dong, Korea
}

\author{
Chan Hee Lee ${ }^{1, *}$, Myoungju Choie ${ }^{2}$ \\ ${ }^{1}$ Department of Cultural Heritage Conservation Sciences, Kongju National University, Gongju 32588, Korea \\ ${ }^{2}$ Conservation Science Division, National Research Institute of Cultural Heritage, 34122, Republic of Korea \\ *Corresponding author : chanlee@kongju.ac.kr
}

\section{ARTICLE INFORMATION}

Manuscript received 22 January 2021

Received in revised form 10 February 2021

Manuscript accepted 11 February 2021

Available online 26 February 2021

DOI : http://dx.doi.org/10.9719/EEG.2021.54.1.137

\section{Research Highlights}

- The Seoak-dong Buddha triad is the rock-carved standing Buddha statues of the Unified Silla era (AD 676 to 935) in Gyeongju, Korea.

- The statue of Amitabha sculptured the andesite slope with biotite granite pedestal and two Bodhisattva parallel made by alkali granites.

- Deteriorations of the Buddha statues are accelerating due to the various discontinuity and biological coverages.

\begin{abstract}
The rock-carved standing Buddha triad in Seoak-dong is a large stone Buddha statue of the Unified Silla era (AD 676 to 935) in ancient Korea, built near the top of the southeastern side of mountain Seondosan in Gyeongju, is characterized by its locational importance, the powerful Amitabha and the gentle sculptural technique of the Bodhisattva. In particular, Amitabha Buddha in andesite rock slope with biotite granite pedestal and two Bodhisattva parallel made by alkali granites seems to express the dignity through the color and texture of the stones. In the Amitabha Buddha, deterioration characteristics are accelerating due to the combination of various joint systems, instability of the slopes and relaxation by the root pressure of plants occurring at the top. In addition, physical properties have deteriorated owing to the increase of discontinuous surfaces as joints, cracks and scalings, and the coverage of algae and lichen is also high. Therefore, deterioration degree in Buddha triad is accelerated due to the physical weathering characteristics from natural rock mass and various biological invasion.
\end{abstract}

Keywords : Rock-carved standing Buddha triad, slope stability, deterioration characteristics, biological invasion

Citation: Lee, C.H., Choie, M. (2021) Evaluation of Stability and Deterioration Characteristics for the Rock-carved Standing Buddha Triad in Gyeongju Seoak-dong, Korea, v.54, p.137-150, doi:10.9719/EEG2021.54.1.137.

This is an Open Access article distributed under the terms of the Creative Commons Attribution Non-Commercial License (http://creativecommons.org/ licenses/by-nc/3.0) which permits unrestricted non-commercial use, distribution, and reproduction in any medium, provided original work is properly cited. pISSN 1225-7281; eISSN 2288-7962/@2021 The KSEEG. Printed by Hanrimwon Publishing Company. All rights reserved. 


\section{연구논문}

\section{경주 서악동 마애여래삼존입상의 손상특성 및 안정성 평가}

\section{이찬희 ${ }^{1, *} \cdot$ 최명주 $^{2}$}

${ }^{1}$ 공주대학교 문화재보존과학과

국립문화재연구소 보존과학연구실

*책임저자 : chanlee@kongju.ac.kr

\section{요 약}

서악동 마애여래삼존입상은 경주 선도산 정상부의 동남향에 조성된 통일신라시대의 거석불로 입지적 중요성과 함께 힘찬 아미 타불상과 부드러운 협시보살의 조각수법이 매우 특징적이다. 특히 안산암질 암반에 불신을 새기고 흑운모화강암을 대좌로 장 식한 아미타불상과 좌우 병렬식으로 배치된 알칼리 화강암으로 조성된 협시불은 석재의 색상 및 질감을 통해 석불의 위엄을 잘 표현하였다. 아미타불상은 암반에 형성된 절리로 인한 불연속면의 발달과 사면의 불안정성, 최상부에서 발생하는 식물의 근압 에 의한 암반의 이완현상이 결부되어 손상이 가속되고 있다. 또한 절리와 균열 및 박리 등 불연속면의 증가로 인해 물성이 크 게 저하되었으며 조류 및 지의류의 피복도가 높은 상태이다. 따라서 마애여래삼존입상에 발생한 손상정도는 아미타불상이 마 애불로 조성되면서 나타난 물리적 풍화특성과 다양한 생물침해에 의해 손상이 가속화되는 것으로 판단된다.

주요어 : 마애여래삼존입상, 사면안정성, 손상특성, 생물침해

\section{1. 서 언}

서악동 마애여래삼존입상(보물 제62호)은 경주 선도산 정상부에서 약 $35^{\circ}$ 로 동남향한 자연암반에 조성된 통일 신라시대 초기의 거석불이다. 선도산은 경주의 서쪽에 위 치하며 중생대 백악기 신라층군의 대구층을 관입 및 분 출한 안산암류가 산지를 이루고 주변으로 언양화강암과 규장암 등이 분포하는 지질특성을 가지고 있다(Fig. 1).

이 삼존불입상은 안산암질 암벽에 높이 $7 \mathrm{~m}$ 정도의 거 대한 아미타여래입상을 본존불로 하여, 왼쪽에는 관음보 살상을 오른쪽에는 대세지보살상을 조각한 7세기 중엽의 삼존불상이다. 그러나 본존불은 두상이 완전히 없어졌고 상호도 심하게 파손된 상태이다. 이는 삼국시대에서 통 일신라시대의 불상조각으로 이어지는 과도기의 중요한 작품이며, 별도의 화강암질암으로 제작한 관음보살상은 높이가 $4.55 \mathrm{~m}$ 정도이고 대세지보살은 $4.62 \mathrm{~m}$ 이다.

통일신라시대에 모량부에 속했던 선도산은 수도에 인 접하여 많은 유적이 남아있으며, 신라인들에게는 설화와 더불어 중요한 신앙처로 인식되어 서악이라 불리며 신성 하게 여겨졌다(National Geographic Information Institute, 2020). 선도산의 동남쪽 계곡에는 신라왕들의 무덤으로 알려진 서악동 고분군과 진흥왕, 진지왕, 문성왕 및 무열 왕 등 신라에서 통일신라시대의 왕릉과 더불어 서악동 삼층석탑 등이 분포하여 이 마애여래삼존입상의 입지적
중요성을 입증하고 있다(Fig. 1).

삼존입상 중 본종불의 도상은 남아 있는 두상 및 윤곽 에서 충만한 힘이 느껴져 보기 드문 득의의 수법으로 조 각된 당대에 유행하던 아미타불상이다. 협시보살은 선이 부드럽고 은은한 미소로 표현된 좌측의 관음보살과 남성 적 기풍으로 표현된 우측의 대세지보살로 조성되어 있으 며, 모두 U자형 턱걸이 받침 대좌위에 안치되어 있다 (Moon, 1969). 이들은 본존불과는 다른 별도의 암석으로 제작하여 옆에 세운 것이다.

이 마애여래삼존입상에 대하여는 산출상태와 암석학적 특징 및 전반적인 풍화와 훼손도 진단을 통하여 보존과 학적 대안이 검토된 바 있다(Lee et al., 2001). 그러나 최 근에도 진행성 손상과 안전성에 대한 문제가 지속적으로 제기되어 왔다(National Research Institute of Cultural Heritage, 2019). 따라서 이 연구는 2011년 (주)동방문화 유산과 수행한 조사를 바탕으로 재검토하여, 서악동 마 애여래삼존입상을 구성하는 암석의 물성과 손상도 평가 및 사면의 불연속면을 분석하고 향후 안정적 보존을 위 한 기초자료를 구축하였다.

\section{2. 현황 및 연구방법}

\section{1. 현 황}

연구대상 삼존입상은 세 불상이 나란히 배치되어 있으 


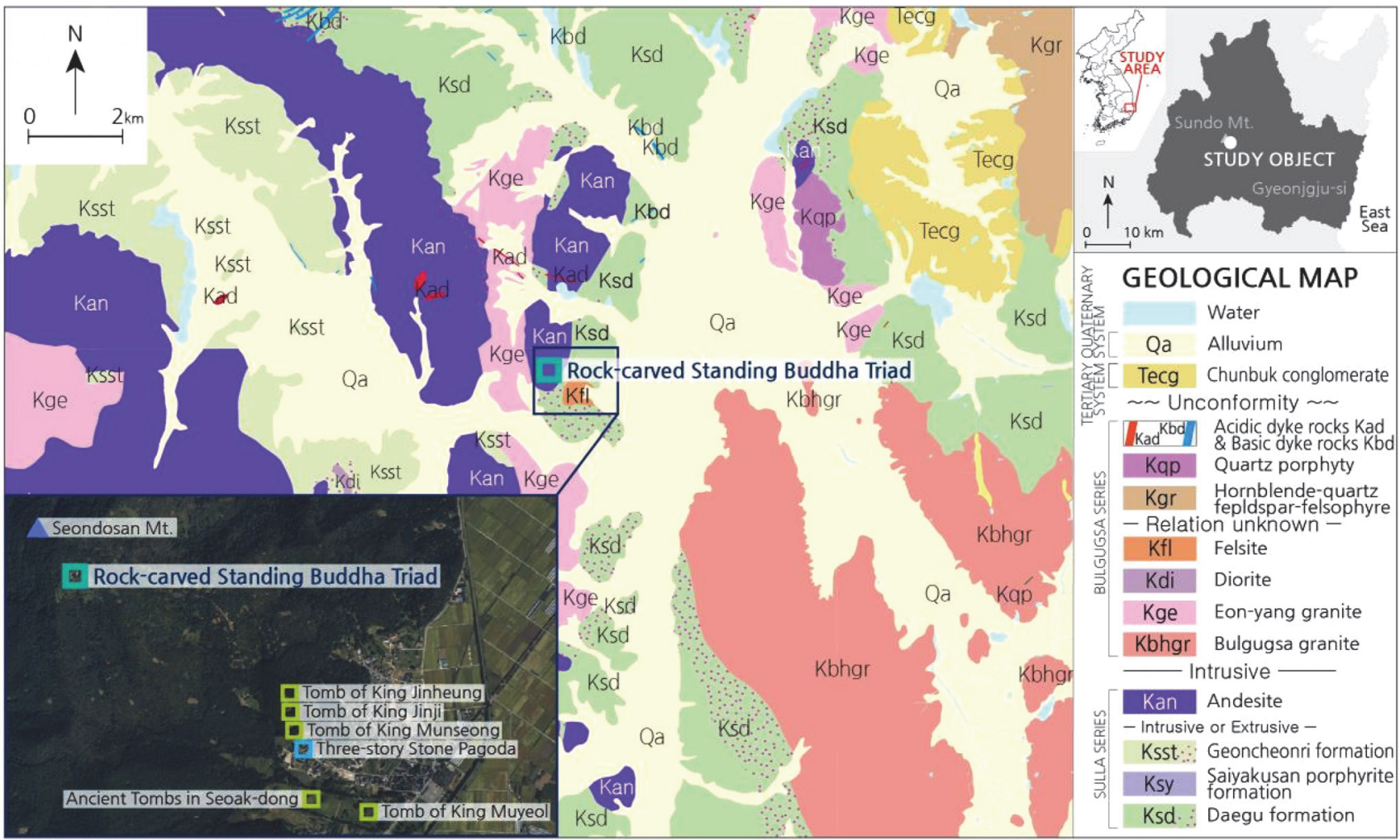

Fig. 1. Location and geological setting around the Buddha triad of Seoak-dong in Gyeongju area. There are many tombs for King from era of Silla to Unified Silla arranged mountain Seondosan slope with the satellite image from Ministry of Land, Infrastructure and Transport of National Geographic Information Institute (2020).

나 본존불(아미타불상)은 암반에 조각되어 돌출된 형태 를 띤 마애불로 암면의 구조적 불연속면을 따라 곳곳에 균열대가 발달한다. 특히 상호의 상부는 소실되었고 법 의의 탈락과 불신의 박리 및 박락 등 전체적으로 물리적 훼손이 심한 상태이다(Fig. 2A).

또한 협시불은 조립이 가능한 대좌를 제외하면 좌협시 불(관음보살)은 세부분으로 나뉘어 있으며, 우협시불(대 세지보살)은 다섯 부분으로 분할되어 있다. 따라서 좌협 시보살의 좌측 어깨에서 허리로 이어지는 도상을 제외한 불신의 조각을 모두 모르타르로 접합하여 보수한 흔적이 나타난다(Fig. 2A, 2I).

한편 화학적 풍화에 의한 갈색 및 흑색 변색이 본존불 을 중심으로 두드러지게 관찰되며, 협시불에는 지의류 피 복 등 생물에 의한 훼손이 나타난다(Fig. 2A 2D). 모르 타르로 수리된 협시불은 1960년대에는 본존불 옆에 분리 된 상태로 보전되고 있다(Fig. $2 \mathrm{E} \sim 2 \mathrm{G}$ )는 기록이 있다 (Jin, 1962). 또한 일제강점기 조사 당시 협시보살의 여러 조각이 계곡에서 발견되었으며(Moon, 1969), 이를 문화 재관리국이 수습하였으나 복원되지 않은 상태였던 것으 로 알려져 있다(Fig. 2H).

이후 보수를 통해 협시보살들의 대좌를 고정하고 모르
타르로 불신의 파편을 접합하여 복원한 후에(Fig. 2I $2 \mathrm{~K})$, 마애여래삼존입상의 기계적 파손과 보존과학적 대 책을 수립하기 위한 연구가 수행되었다(Lee et al., 2001). 이 때 암반에 발달한 절리대, 토압 및 편압력, 전단응력, 포행 등의 구조적 불안정성과 잡초와 수근에 의한 암반 의 기계적 풍화를 제어하기 위한 방안도 검토되었다.

그러나 본존불 불두 상부의 유실 시점 및 원형에 대한 기록은 찾을 수 없어 도상을 유추하기는 어렵다. 사진기 록을 바탕으로 변화 양상을 살펴보면, 균열 등 물리적 훼 손에 따른 도상의 손상은 추가적으로 발생하지 않았음을 알 수 있다. 또한 목본식물의 식생영역이 본존불이 조각 된 암반 상부까지 전진하여 식생의 뿌리에 의한 기게적 풍화가 시간이 흐름에 따라 가속되고 있는 것을 볼 수 있다(Fig. 2A, 2E).

\section{2. 연구방법}

석조문화유산의 보존과학적 연구는 보수를 위한 대체 석재 탐색 및 동질성 분석과 실제적 적용(Lee et al., 2007; 2010; 2011; Kim et al., 2011)을 중심으로 손상도 및 물 성평가, 구조안정성 분석, 미시환경 평가 및 모니터링, 과 학적 보존처리 등이 지속적으로 보고되고 있다(Lee et al., 

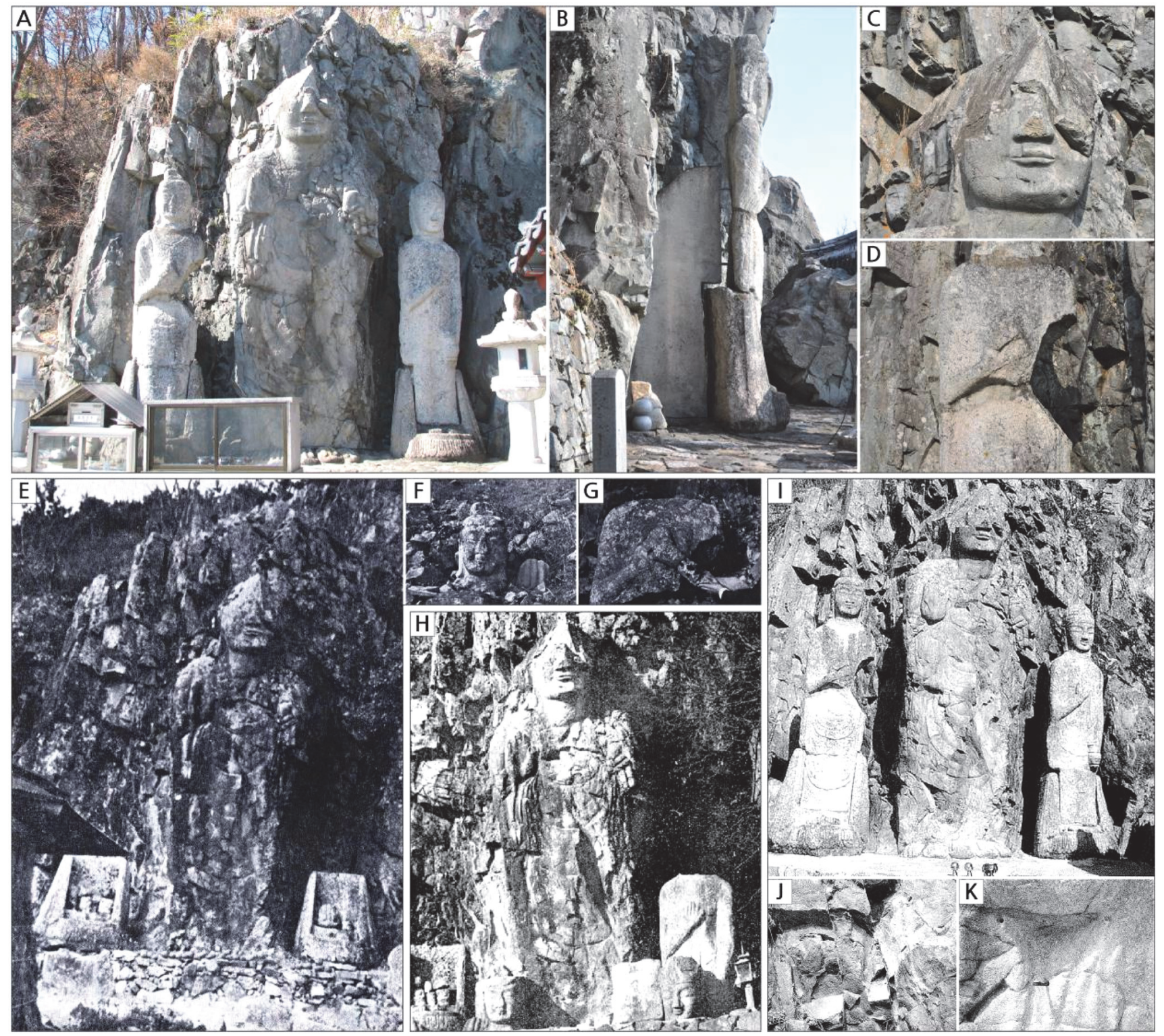

Fig. 2. Present and historical status for conservation condition of the Buddha triad in Seoak-dong. (A to D) Current condition of the Buddha triad. (E to G) Ancient photographs of the Buddha triad (Jin, 1962). Statues of Avalokitesvara Bodhisattva (left) and Mahasthamaprapta Bodhisattva (right) and pedestal of Amitabha Buddha were found damaged. (H) Before conservation affairs of the Buddha statues (Moon, 1969). (I to J) After conservation recovery of the Buddha triad (Lee et al., 2001).

2006; 2012; 2017; Lee and Araki, 2019). 이 연구에서도 다양한 풍화에 따른 손상과 보수를 반복하고 있는 서악 동 마애여래삼존입상의 전반적인 손상도 및 물성 분석을 통한 안정적 보존방안을 검토하기 위해 다음과 같은 연 구방법을 적용하였다.

삼존입상을 구성하는 암석의 재질특성과 조암광물 및 산출상태를 기재하고자 정밀 육안관찰을 통해 암종을 분 류하고, ZH Instrument의 SM30 모델의 대자율 측정기로 모암의 미세자화 특성을 분석하였다. 또한 현장에서 수 습한 미세암편을 대상으로 Nickon Eclipse E600W 편광
및 반사 겸용현미경과 Rigaku D/Max-IIb모델의 X-선 회 절분석기를 이용하여 미세조직과 조암광물을 분석하였다. 전체적인 손상상태는 육안관찰을 토대로 크게 물리적, 화학적, 생물학적 및 인위적 훼손으로 대분하고 AutoCAD 와 Adobe Illustrator를 활용하여 Jo and Lee(2011)의 방 법에 따라 손상지도를 작성하고 손상률을 산정하였다. 이 때 본존불의 불두 훼손부는 원래의 형태 및 크기를 알 수 없고 명확한 도상 영역의 확정이 불가하여 가장 오래 된 1962년의 기록을 영역산정의 기준으로 삼았다. 이 과 정에서 본존불의 두드러진 균열은 면적대비 총길이를 반 
영하는 균열지수(CI; crack index)를 적용하였다.

삼존입상의 표면에 나타난 박리와 박락을 검출하기 위 해 타진법을 이용할 경우 도상의 파손을 유발할 수 있다. 따라서 이 연구에서는 Jo and Lee(2014a; 2014b)가 제시 한 기법을 적용하여 FLIR의 모델 B200 적외선 카메라와 적외선 열원을 사용하고 표면임계온도 분석을 통해 비파 괴로 박리영역을 기록하였다. 또한 본존불의 입술과 법 의에 남아있는 적색 안료는 원래의 분포 범위를 알 수 없으나, 다른 무기오염물과 함께 성분을 검출하기 위해 Innov-X System $\alpha-4000$ 모델의 P-XRF로 분석하였다.

특히 본존불과 기반암의 암반사면에 분포하는 뚜렷한 물리적 손상 및 불연속면의 주향과 경사에 대하여 Nihon Chikagaky 클리노미터로 측정하였으며, 이를 DIPS 프로 그램에 적용하여 사면안정성 및 파괴가능성을 탐색하였 다. 또한 Proceq의 Pundit Lab 모델과 CNS Farnell의 $\operatorname{Utrextx}(\mathrm{RX}) 54 \mathrm{kHz}$ 탐촉자 및 엘라스토머커버를 이용하 여 암석의 초음파 물성을 측정하였으며 풍화등급 산출 및 균열과 물성분포와의 상관성을 고찰하였다. 이와 같 은 최근의 연구는 Yang et al.(2020)의 보고가 있다.

\section{3. 결과 및 해석}

\section{1. 암석학적 특성}

연구대상 마애여래삼존입상에서 본존을 이루는 아미타 불상은 기반암인 안산암질암에 새겨진 마애불이며, 좌우 의 관음보살상과 대세지보살상은 알칼리 화강암의 별석 으로 제작하여 배치한 협시불이다. 또한 본존불의 대좌 는 흑운모 화강암이며, 두 협시불의 대좌는 홍장석 화강 암이다(Fig. $3 \mathrm{~A})$. 각각의 석재에 대하여 육안관찰 및 전 암대자율 측정 $\left(\times 10^{-3} \mathrm{SI}\right.$ unit $)$ 을 통한 비파괴 분석을 수행 하고, 시료수습이 가능한 안산암 및 화강암에 대하여 편 광현미경 관찰과 $\mathrm{X}$-선 회절분석을 통해 암종과 조직 및 조암광물을 동정하였다.

본존불의 모암인 안산암질암은 부분적으로 열변질을 받았으며, 아미타불상의 도상영역에서는 대체로 암회색 내지 암녹색에 괴상의 균질한 비현정질 조직을 보인다. 암면에서는 쐐기상 내지 판상의 쪼개짐이 발달하며 모암 의 분출과정에서 냉각과 수축으로 인하여 다양한 방향성 을 가진 불연속면이 형성된 것을 볼 수 있다(Fig. $3 \mathrm{~A}$ ).

이 암석은 3.47 23.46(평균 $15.22 \times 10^{-3} \mathrm{SI}$ unit) 범위의 비교적 강자성을 갖는 대자율을 보였다. 편광현미경 및 $\mathrm{X}$-선 회절분석으로는 누대조직을 갖는 사장석 반정이 견 운모화 작용을 받았으며, 세립의 녹니석과 각섬석 및 미 립의 석영이 동정되어 전형적인 안산암임을 지시하였다 (Fig. 3B 3D, 3G). 이들의 산출상태와 조직 및 조암광물
등의 기재적 특징은 Lee et al.(2001)이 비교적 상세하게 보고하였다.

좌우의 협시불을 구성하는 암석은 작은 정동조직이 발 달한 알칼리 화강암으로 선도산 일대에는 분포하지 않는 암석이며, 경주 남산화강암과 매우 유사하다(Lee et al., 2001). 대자율 측정 결과, 관음보살상의 불신은 0.41 1.21(평균 0.66)의 범위를 보이며, 대세지보살상의 불신은 0.44 1.26(평균 0.73)로 유사한 값을 보였다(Fig. 3B).

이 암석은 시편을 수습할 수 없어 육안으로 암상을 동 정한 결과, 전체적으로 회백색을 띠고 중립의 등립질 조 직을 가지며 알칼리 장석, 석영, 흑운모 및 자철석 등이 조암광물을 이룬다(Fig. $3 \mathrm{E}, 3 \mathrm{~F})$. 입상조직을 갖는 조암 광물 사이에는 요철이 있어 조류와 지의류 및 미소토양 이 고착되어 있는 등 표면에 유무기오염물이 산재한다.

한편 좌우 협시불의 받침으로는 홍장석 화강암이 활용 되었으며 중립의 홍색 알칼리 장석, 석영 및 유색광물 등 이 중립의 등립질 입상조직을 이루나, 부성분 광물을 명 확히 관찰하기 어려울 만큼 표면에 생물 및 토양 피복층 이 형성되어 있다. 이들의 대자율 값은 관음보살의 대좌 가 2.11 3.99(평균 3.10)의 범위를, 대세지보살의 대좌는 2.17 3.67(평균 2.71)의 범위를 보여 거의 동일한 자화 강도를 가지고 있다.

본존불의 대좌를 구성하고 있는 석재는 흑운모 화강암 으로 중립질의 등립상 입상조직을 가지며 조암광물로는 알칼리 장석, 사장석, 석영 및 흑운모 등이 관찰된다. 대 자율 측정 결과, 8.78 12.10(평균 10.35)의 범위를 보여 협시보살을 이루는 화강암과는 확연히 다른 자화강도를 지시하였다(Fig. 3B).

\section{2. 손상특성 및 평가}

석조문화재는 암석의 풍화작용에 따라 다양한 손상특 성이 나타나며 일반적으로 물리적, 화학적, 생물학적 및 인위적 손상으로 분류하여 도시하고 손상유형의 점유율 을 산출하여 평가한다(Fitzner and Heinrichs, 2001; Fitzner et al., 2003; Jo and Lee, 2011). 이를 바탕으로 연구대상 마애삼존불입상의 손상특성을 규명하기 위해 실측도면에 각각의 손상유형을 기호화하여 손상지도를 작성하고, 이 를 통해 손상요인과 현상을 정량적으로 파악하여 보존관 리의 자료로 활용하고자 하였다(Fig. 4, Table 1).

이 연구에서는 마애여래삼존입상의 전체적인 손상률을 산출하기 위한 영역 및 면적을 설정하였으며, 마애불 암 반은 $29.29 \mathrm{~m}^{2}$, 본존불 $11.48 \mathrm{~m}^{2}$, 좌협시불 $4.44 \mathrm{~m}^{2}$ 및 우협 시불 $4.42 \mathrm{~m}^{2}$ 로 산정하였다. 이를 반영하여 손상지도 및 손상율을 산출하면, 삼존불에서는 대체로 불상의 파편화 및 손실을 야기하는 물리적 손상과 식생의 피복에 따른 

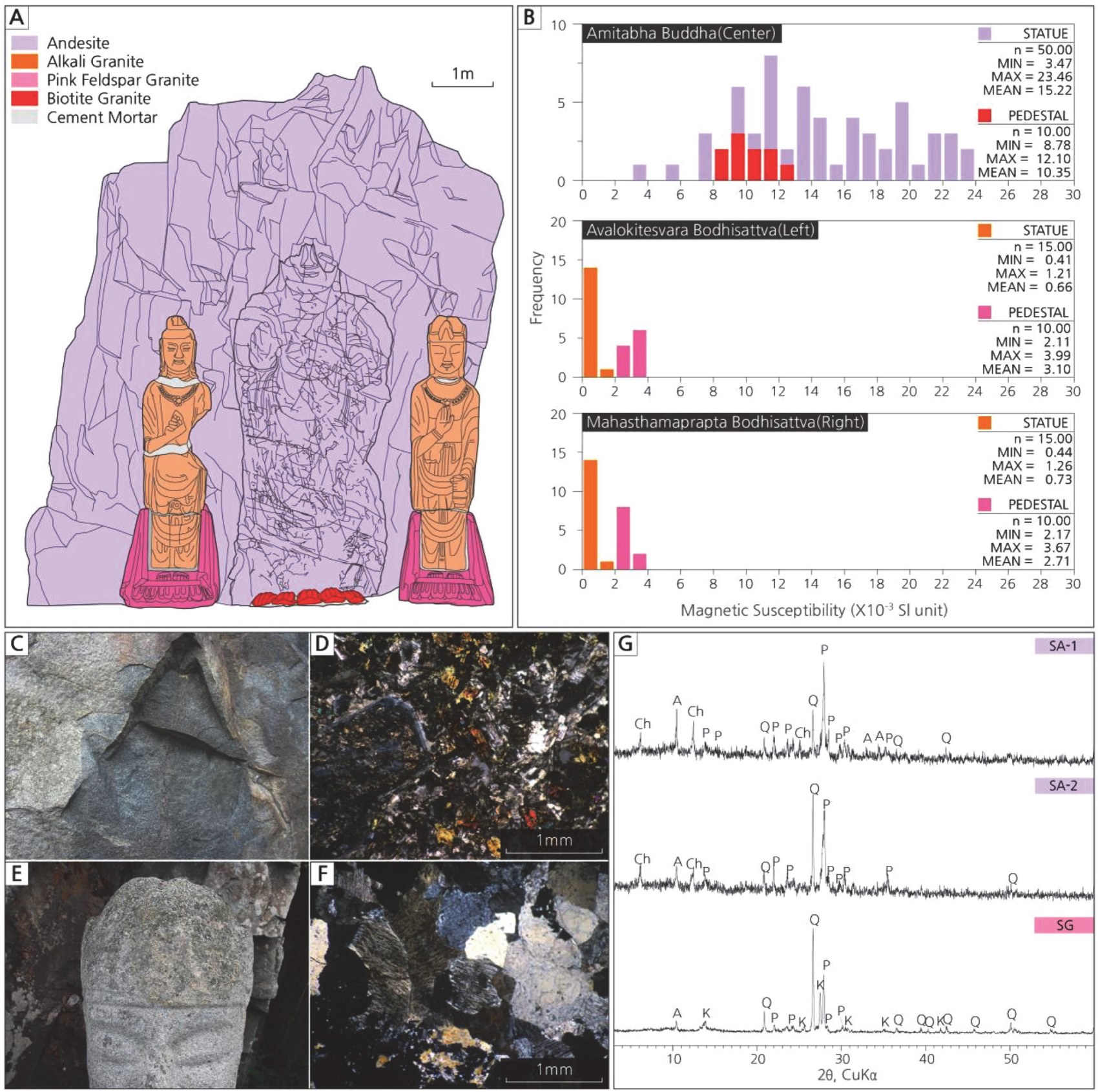

Fig. 3. Petrographic constitutions and some analysis of the Buddha triad in Seoak-dong. (A) Distribution of rock types and conservation material of cement mortar. (B) Magnetic susceptibilities showing the different distributions by rock properties. (C, D) Photograph and polarizing microphotograph of andesite for host rock in center of Amitabha statue. (E, F) Photograph and polarizing microphotograph for alkali granite in left and right of two Bodhisattva statues. (G) X-ray powder diffraction patterns of host rocks for the Buddha triad. Ch; chlorite, Q; quartz, P; plagioclase, K; alkali feldspar, A; amphibole.

생물학적 손상이 우세하게 나타났다(Fig. 4 및 Fig. 5).

연구대상 마애여래삼존입상에는 물리적으로 불연속면 이 발달하여 암편의 손실과 불안정성을 야기하는 균열이 매우 다양하게 분포한다(Fig. 4 및 Fig. 5). 이 균열은 모 암의 암석학적 특성에 따라 발생한 것으로 연장성이 양 호한 구조적 균열이다. 또한 암면에 판상 내지 동심원상
으로 표면과 거의 평행하게 불연속면이 성장하는 박리상 균열도 산재한다. 이들은 서로 중첩되어 암편의 탈락을 유발하는 미세균열 등이 복합적으로 나타난다.

이 연구의 대상영역에서 암반에 분포하는 균열의 총 길 이는 $133.0 \mathrm{~m}$ 이며, 본존불에 발달한 균열의 총 길이는 $127.2 \mathrm{~m}$ 로 나타났다. 이를 Jo and Lee(2011)가 제시한 면 

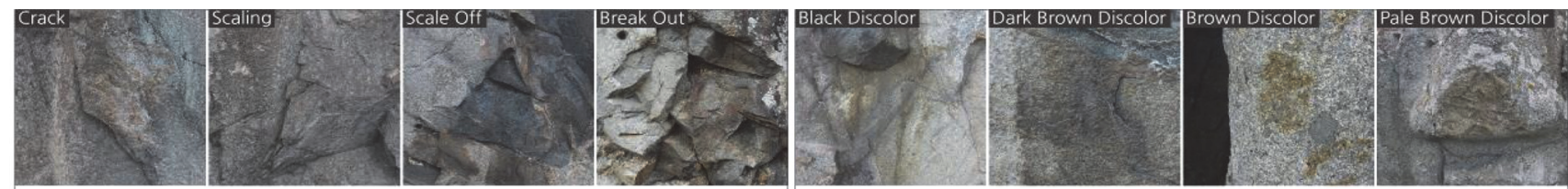

PHYSICAL DETERIORATION MAP

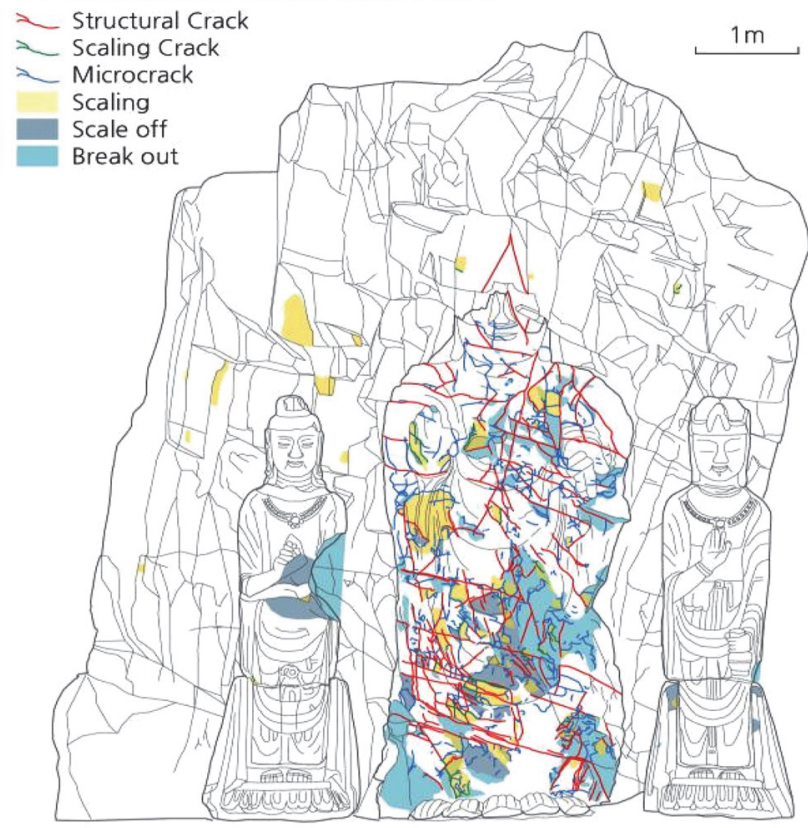

\section{CHEMICAL DETERIORATION MAP}
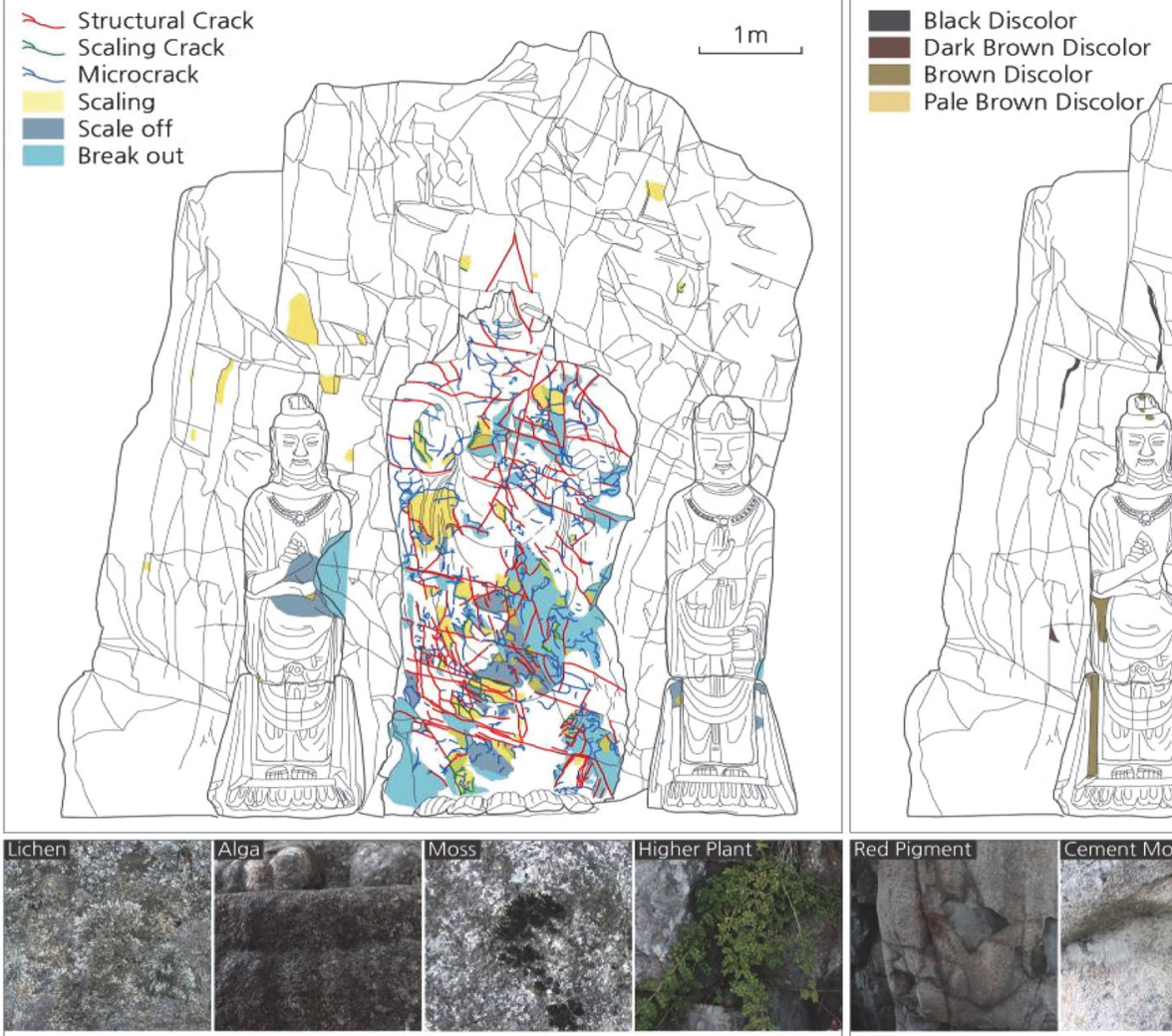

\section{BIOLOGICAL DETERIORATION MAP}
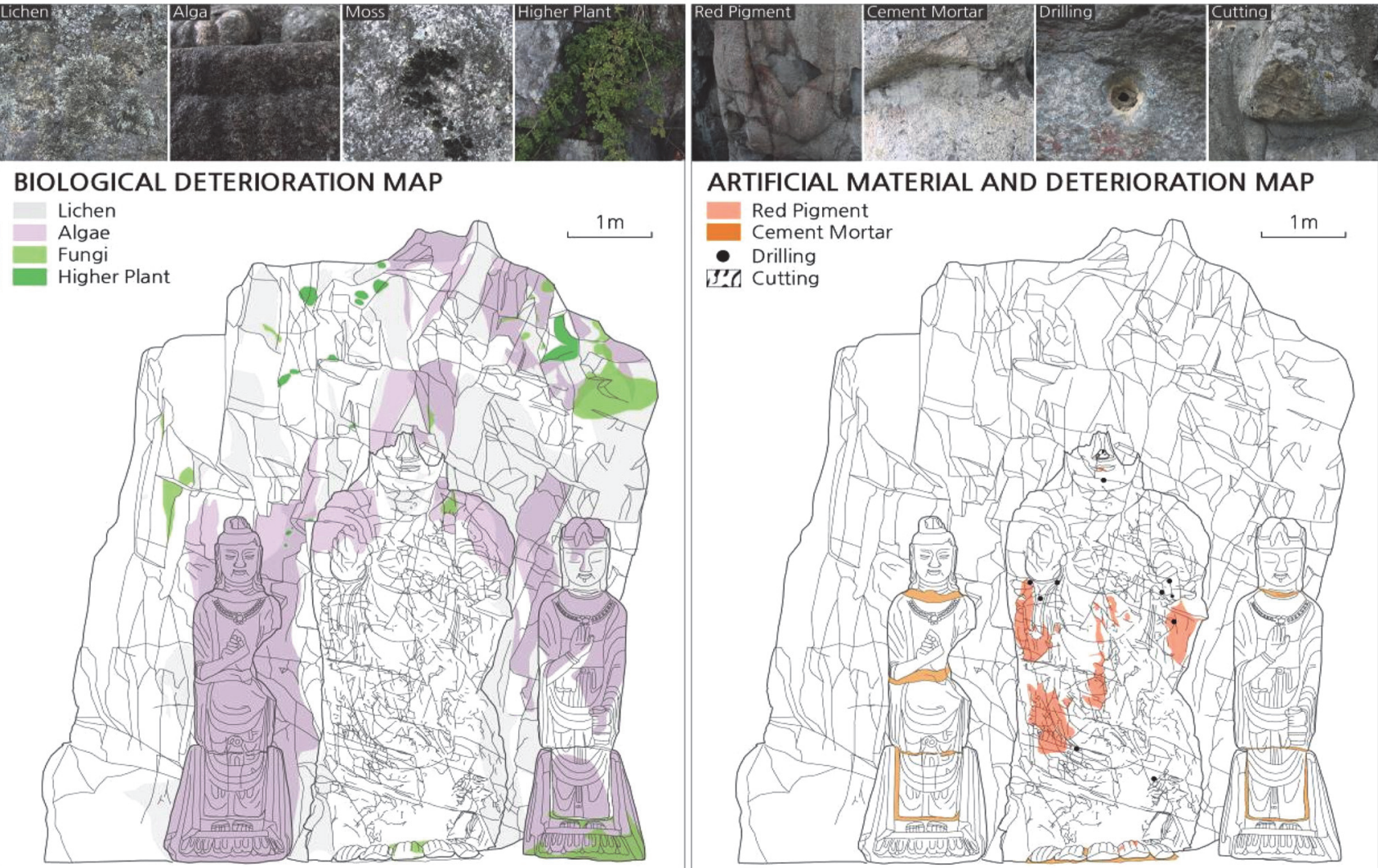

ARTIFICIAL MATERIAL AND DETERIORATION MAP

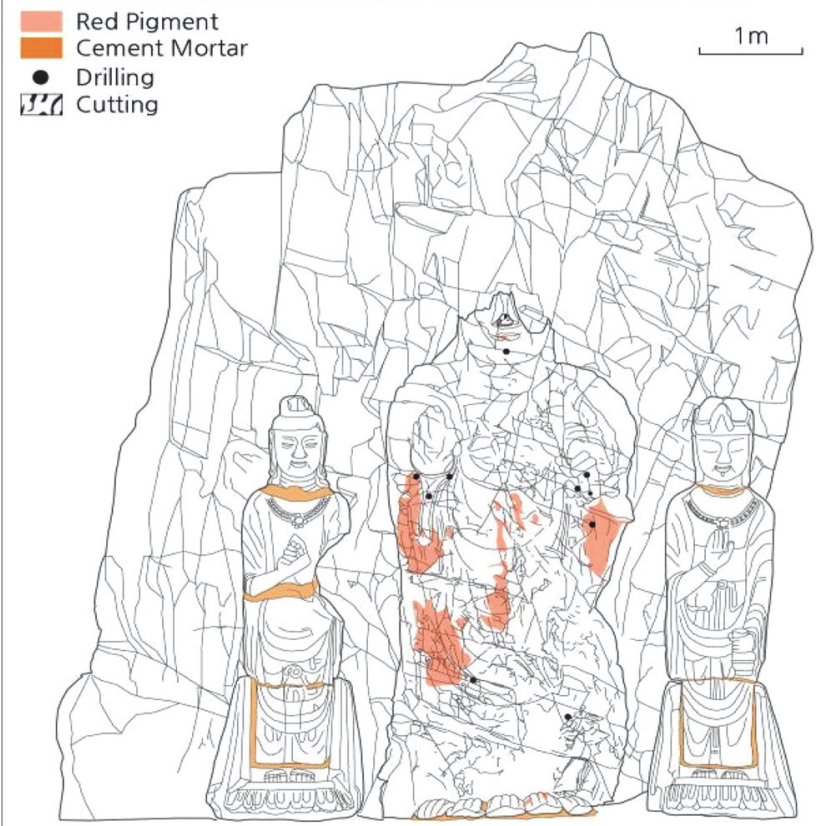

Fig. 4. Simplified physical, chemical, biological and artificial deterioration maps and representative photographs of the Buddha triad in Seoak-dong. Cement mortars for conservation treatments and traces of red pigments were combined with artificial deteriorations. The Buddha triad was occurred physical and biological deterioration types, predominantly. 
Table 1. Summary on representative surface deterioration rate of the Buddha triad in Seoak-dong and its host rock

\begin{tabular}{|c|c|c|c|c|c|c|c|c|c|c|}
\hline & \multicolumn{2}{|c|}{ Host Rock } & \multicolumn{2}{|c|}{$\begin{array}{c}\text { Standing } \\
\text { Buddha Triad }\end{array}$} & \multicolumn{2}{|c|}{$\begin{array}{l}\text { Amitabha } \\
\text { Buddha }\end{array}$} & \multicolumn{2}{|c|}{$\begin{array}{c}\text { Two } \\
\text { Bodhisattvas }\end{array}$} & \multicolumn{2}{|c|}{ Total Area } \\
\hline & $\begin{array}{c}\mathrm{SA} \\
\left(\mathrm{m}^{2}\right)\end{array}$ & $\begin{array}{l}\text { DR } \\
(\%)\end{array}$ & $\begin{array}{c}\mathrm{SA} \\
\left(\mathrm{m}^{2}\right)\end{array}$ & $\begin{array}{l}\text { DR } \\
(\%)\end{array}$ & $\begin{array}{c}\mathrm{SA} \\
\left(\mathrm{m}^{2}\right)\end{array}$ & $\begin{array}{l}\text { DR } \\
(\%)\end{array}$ & $\begin{array}{c}\mathrm{SA} \\
\left(\mathrm{m}^{2}\right)\end{array}$ & $\begin{array}{l}\text { DR } \\
(\%)\end{array}$ & $\begin{array}{l}\text { SA } \\
\left(\mathrm{m}^{2}\right)\end{array}$ & $\begin{array}{l}\mathrm{DR} \\
(\%)\end{array}$ \\
\hline Scaling & 0.273 & 0.93 & 1.010 & 4.97 & 0.999 & 8.70 & 0.012 & 0.13 & 1.283 & 2.59 \\
\hline Scaling off & - & - & 0.846 & 4.16 & 0.602 & 5.25 & 0.244 & 2.76 & 0.846 & 1.71 \\
\hline Break out & - & - & 2.806 & 13.80 & 20561 & 22.32 & 0.245 & 2.76 & 2.806 & 5.65 \\
\hline Black & 0.312 & 1.07 & 0.015 & 0.07 & 0.150 & 0.13 & - & - & 0.327 & 0.66 \\
\hline Dark Brown & 0.056 & 0.19 & 0.500 & 2.47 & 0.503 & 4.39 & - & - & 0.560 & 1.13 \\
\hline Brown & - & - & 0.018 & 0.86 & - & - & 0.177 & 1.98 & 0.175 & 0.35 \\
\hline Pale Brown & - & - & 0.164 & 0.80 & 0.164 & 1.42 & - & - & 0.164 & 0.33 \\
\hline Lichen & 12.540 & 42.82 & 9.106 & 44.76 & 1.242 & 10.83 & 7.861 & 88.72 & 21.647 & 43.61 \\
\hline Algae & 5.428 & 18.53 & 8.697 & 42.76 & 1.178 & 10.27 & 7.518 & 84.84 & 14.125 & 28.46 \\
\hline Moss & 0.771 & 2.63 & 0.469 & 2.31 & 0.084 & 0.74 & 0.384 & 4.34 & 1.240 & 2.50 \\
\hline Higher Plant & 0.261 & 0.89 & - & - & - & - & - & - & 0.262 & 0.53 \\
\hline Red Pigment & - & - & 0.931 & 4.58 & 0.931 & 8.12 & - & - & 0.931 & 1.88 \\
\hline Cement Mortar & - & - & 0.423 & 2.08 & 0.060 & 0.53 & 0.362 & 4.09 & 0.423 & 0.85 \\
\hline Drilling & - & - & 0.008 & 0.04 & 0.008 & 0.07 & - & - & 0.008 & 0.02 \\
\hline Cutting & - & - & 0.013 & 0.06 & 0.013 & 0.12 & - & - & 0.013 & 0.03 \\
\hline
\end{tabular}

SA; surface area, DR; deterioration rate.
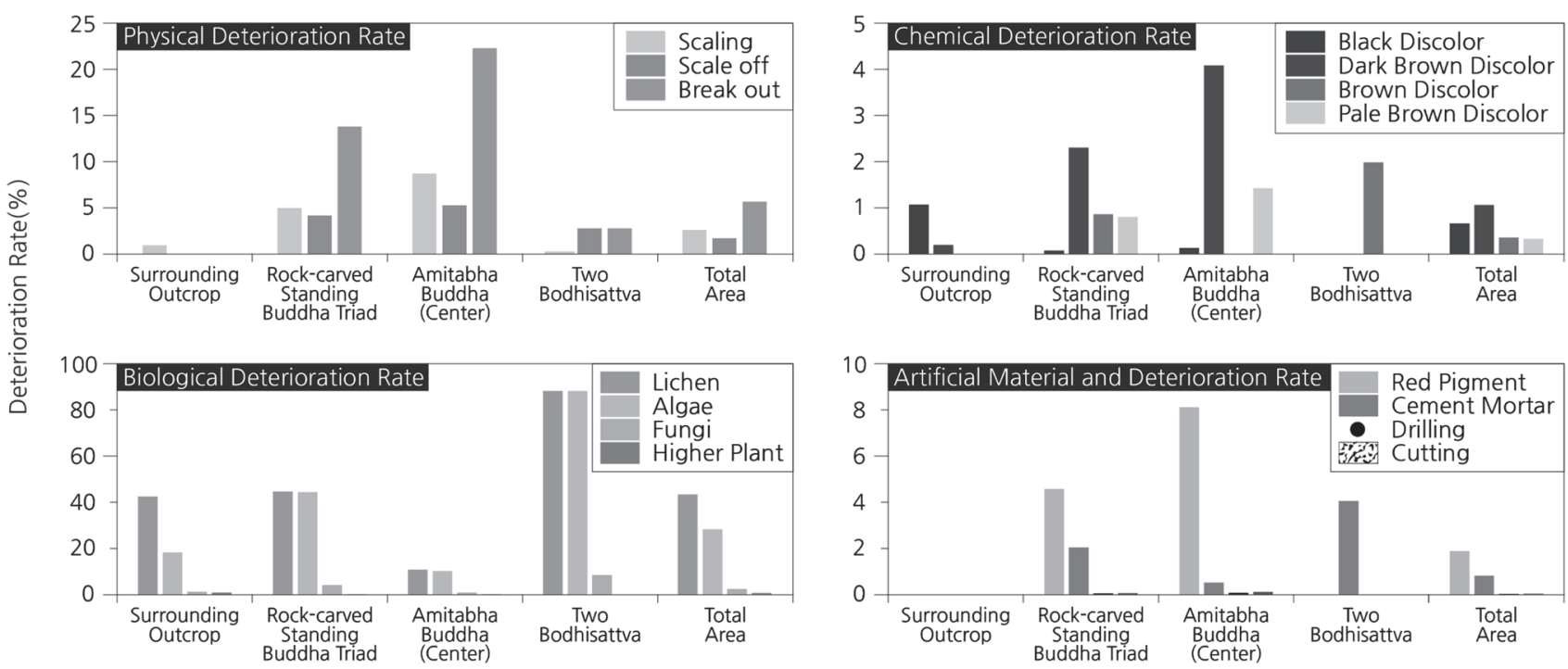

Fig. 5. Histograms showing deterioration rate of the Buddha triad in Seoak-dong. The highest deterioration rate is biological coverage on two Bodhisattvas caused by lichen and algae. The red pigments have limited distribution in center Amitabha Buddha only based on artificial material rate.

적 대비 균열의 총 길이를 지시하는 균열지수 $(\mathrm{CI})$ 에 대 입하면, 암반에서는 24.6이며 본존불은 37.6으로 산출되 어 본존불에서 볼 수 있는 복합적인 균열양상이 균열지 수의 차이를 유발한 것으로 판단할 수 있다.

또한 암석 표면의 박리상 균열로 인하여 들뜬 영역을 일컫는 박리 $(2.59 \%)$ 와 이들의 심화에 따라 실질적 손실
이 나타난 박락 $(1.71 \%)$ 및 물리적 충격을 받아 불연속면 에서 암편이 분리되어 떨어져 나간 탈락 $(5.65 \%)$ 등도 발 생하여 삼존불의 도상을 크게 훼손하였다. 특히 본존불 의 불두 상부는 두 방향의 절리면이 교차하며 암석의 탈 락으로 인해 가장 두드러지게 발생한 손실의 형태이다. 우협시불도 석재의 탈락에 의해 좌측 허리에서 손실 영 
역이 크게 나타난다(Fig. 4 및 Fig. 5).

이 마애여래삼존입상의 화학적 손상은 조암광물의 구 성원소가 산화에 의해 용출되어 농축되거나 안료의 열화 및 고착생물의 고사 등이 복합적으로 작용하여 표면오염 을 유발한 것으로 나타난다. 특히 흑색 $(0.66 \%)$ 내지 적 갈색 $(1.13 \%)$ 변색은 암반의 불연속면을 따라 하부로 물 의 유동을 따라 분포하는 특성이 있고, 갈색 $(0.35 \%)$ 및 연갈색 $(0.33 \%)$ 변색은 특별한 유동흔적이 없이 곳곳에 산재되어 있다.

한편 연구대상 삼존불상은 입지가 산지의 거의 정상부 로, 본존불을 조성한 자연암반의 상부와 주변에는 초본 및 목본식물이 무성하게 생장하고 있으며, 이 암반은 식 물착생에 매우 유리한 환경을 갖추고 있다. 따라서 지의 류(43.61\%)와 조류(28.46\%) 및 선태류(2.50\%)와 같이 피 도가 높은 고착성 미생물을(Fig. 4 및 Fig. 5), 열화과정 에서 부식성 산을 배출하여 암석의 조암광물을 분해한다. 이는 암석의 알칼리화와 변질을 수반하여 섬유질과 균 사의 침투로 인한 공극형성과 입자조직을 이완시키는 것 으로 알려져 있다(Crispim and Gaylarde, 2004). 상부의 식생대는 이 연구의 손상지도 영역에 포함되지는 않아 영향을 완전히 대변할 수는 없으나, 마애불 상부에 착생 한 고등식물 $(0.53 \%)$ 은 양분을 흡수하기 위하여 불연속면 에 파고들어 근압에 따른 암반의 내부팽창을 야기하고 있을 것으로 보인다.

본존불의 표면에 나타난 인위적 물질은 불상을 조성하 고 채색하는 과정에서 사용한 적색 또는 적황색 안료 $(1.88 \%)$ 와 파손부분의 보수를 위하여 접합제로 사용한 시 멘트 모르타르 $(0.85 \%)$ 등이 있다. 특히 적색 계통의 안 료는 아미타불상의 입술 및 법의에 부분적으로 분포하나 상당 부분의 칠이 벗겨지거나 박락 및 탈락으로 인하여 원래의 분포영역을 확정하기 매우 어려운 상태이다(Fig. 4 및 Fig. 5).

또한 본존불의 암면 곳곳에는 암편의 탈락 및 균열과 같은 물리적 손상을 제어하기 위해 천공 $(0.02 \%)$ 하여 청 동 나사못을 박았던 흔적이 산재한다. 또한 무분별한 민 간신앙 등으로 인해 불상 조성 이후 인위적 연마에 따른 삭박 $(0.03 \%)$ 과 기도흔적 및 낙서와 같은 인위적 손상유 형들이 다양하게 노출되어 있는 상태이다.

\section{3. 사면안정성 분석}

본존불이 조성된 암반은 중첩된 절리계의 형성으로 크 고 작은 불연속면이 다양하게 분포하며 불두 및 법의에 서 암편의 탈락을 야기하였다. 또한 대기에 노출된 이래 동결융해의 반복에 따른 쐐기작용과 수목의 근압과 팽창 등에 의해 암석이 파편화가 지속되고 있다. 본존불은 약 $5^{\circ}$ 정도 전방으로 기울어져 토양 및 암편의 포행에 따라 압력이 발생하고 있어 사면파괴의 위험성도 보고된 바 있다(Lee et al., 2001). 따라서 파괴의 유형 및 가능성을 예측하고 선제적 조치 및 모니터링을 통한 지속적인 관 리가 필요하다.

평사투영법을 적용하여 사면파괴의 가능성을 검토할 본존불 영역은 $7.3 \times 8.4 \mathrm{~m}$ 로 설정하였으며, 이 암반의 좌 우에는 최장 $5.1 \mathrm{~m}$ 와 상하로 최장 $4.8 \mathrm{~m}$ 의 구조적 절리계 가 분포한다. 이를 기준으로 불연속면이 발달영역을 총 6개 구역으로 세분하였다(Fig. 6). 여기에는 불상조각의 돌출부와 문양 등을 3 차원 공간의 평면화로 인해 형태의 왜곡이 발생할 수 있어 파괴에 의해 노출된 절리면에 번 호를 부여하고 도시화하였다.

이 불연속면들의 모든 주향과 경사를 측정하여 장미도 표에 도시하고 이를 평사투영하여 파괴유형 및 가능성을 예측하였다. 여기에는 Lee et al.(2012) 및 Odonne et $a l$ (2007)등에 의해 검증된 기법을 활용하였다. 또한 $\operatorname{Barton}(1973 ; 1976)$ 의 보고를 근거로 30 35의 마찰각을 적용하고 가장 위험한 상황을 가정하여 해석하였다.

이 결과, 본존불과 기반암에 발달한 주요 불연속면의 주향은 $\mathrm{N} 40 \sim 85^{\circ} \mathrm{W}$ 와 $\mathrm{N} 40 \sim 80^{\circ} \mathrm{E}$ 이며 이들의 경사는 50 $\sim 85^{\circ} \mathrm{SW}$ 및 $60 \sim 85^{\circ} \mathrm{NE}$ 로 두 절리계가 고각으로 교차하 는 것이 가장 우세한 것으로 나타났다. 이를 유형에 따 라 세분하면 평면파괴가 8 개 지점에서 전도파괴가 6 개 지점에서 발생할 가능성이 있는 것으로 예측되었다. 특 히 전도파괴의 발생가능 구역이 암반사면의 비교적 높은 곳에 위치하여 암편의 탈락으로 인한 협시불이 타격을 받을 수도 있는 상황이다(Fig. 6).

이 암반에 설정한 기준사면 $\left(\mathrm{N} 35^{\circ} \mathrm{E}\right.$ 및 $\left.85^{\circ} \mathrm{NW}\right)$ 에 대하 여 쐐기파괴 가능성을 도시한 결과, 본존불의 불두에 해 당되는 $\mathrm{A}$ 구역은 상부의 네 지점에서 이미 파괴이력이 확 인되었으며 좌측의 소형 암편들은 세 지점에서 추가적인 파괴의 가능성이 예측되었다(Fig. 6). 또한 불신의 상부 영역인 $\mathrm{B}$ 구역은 3 개 지점에서 파괴 가능성이 있으나 최 근까지 파편화된 암편은 비교적 적게 나타난다.

본존불 불신의 중앙부에 해당하는 $\mathrm{C}$ 구역은 이미 사면 의 파괴가 진행된 두 지점이 있으나, 추가적인 파괴 가 능성은 보이지 않아 상대적으로 안정한 상태이다. D구역 인 불신의 하부는 비교적 불연속면의 연장성이 낮은 절 리들이 교차하여 국부적인 파괴 가능성이 발견된다(Fig. 6). 그러나 절리의 발달에 따라 연장되어 교차하는 다른 절 리와 만날 경우 더 큰 규모의 파손을 예상할 수 있다.

불상의 우측 암반사면 영역에 해당하는 $\mathrm{E}$ 구역은 한 개 의 탈락지점과 여섯 개의 붕괴 가능 지점이 있다. 이 부 분은 불연속면이 형성된 암편의 규모가 크고 하중을 지 


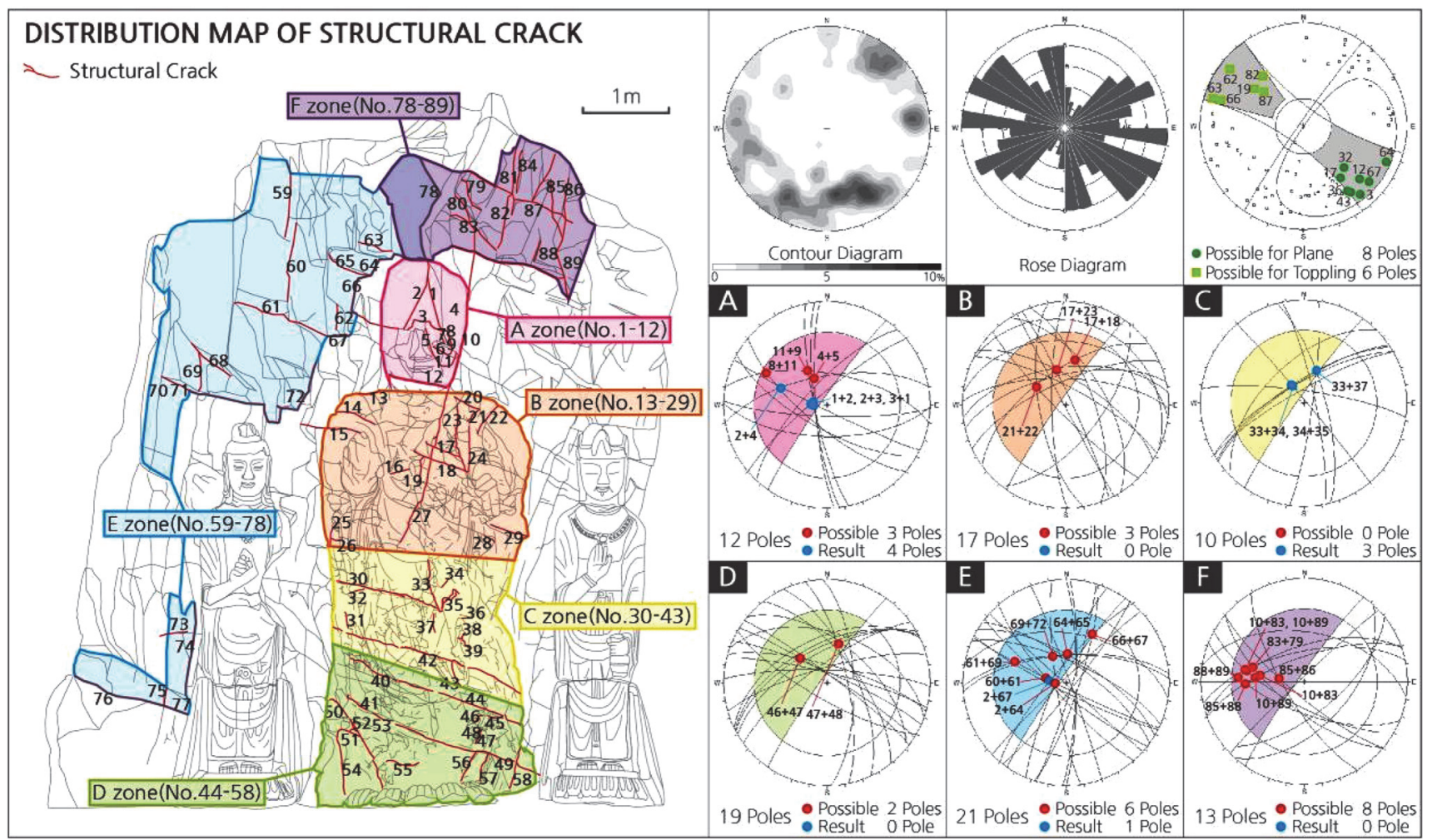

Fig. 6. Distribution map of structural crack and possible failure types (after Varnes, 1978) showing the host rock and Amitabha Buddha in natural rock slope of the Buddha triad in Seoak-dong. Study area contains 8 and 6 possible zones of plane and toppling failure, respectively. The $\mathrm{E}$ and $\mathrm{Z}$ zones have a highly possible wedge failure (each 6 and 8 zones) and may cause secondary physical deterioration to the two Bodhisattva statues.

지해줄 수 있는 하부 암반이 없어 상당히 높은 불안정성 을 가지고 있다(Fig. 6). 좌측 암반사면은 우측에 비해 암 편의 크기는 작으나 총 여덟 지점에서 파괴의 가능성이 있는 것으로 나타나 이에 대한 적극적인 대비가 필요한 상태로 해석하였다.

\section{4. 초음파 물성분석}

안산암으로 이루어진 본존불과 화강암으로 조성된 협 시보살 및 본존불의 대좌를 대상으로 석조문화재의 대표 적인 비파괴 분석인 초음파속도를 측정하여 암석의 물성 을 파악하였다. 측정은 간접적 속도전달 방식으로 수행 하여 획득한 초음파 속도를 각각의 암석에 적합한 보정 계수를 대입하여 직접법의 음속차로 보정하였다. 이는 다 양한 석조문화재에 적용하여 신뢰도가 검증된 방법이다 (Lee et al., 2009; Lee and Jo, 2017; Jo and Lee, 2014c; 2015). 또한 이 결과를 2D 모델링하고 본존불 영역의 균 열도와 중첩하여 상관관계를 분석하였다(Fig. 7).

불연속면이 발달한 암석의 초음파 측정은 균열 깊이 $200 \mathrm{~mm}$ 이내의 범위에서 탐촉자의 측정거리가 동일하거 나 작을 때 근접한 값을 산출하지만 깊이가 $250 \mathrm{~mm}$ 이
상일 경우에는 오차가 커진다(Rhim et al., 2002). 연구대 상 본존불 표면에는 크고 작은 균열계가 수평(A군)과 사 교(B군) 및 수직(C군)으로 복잡하게 연장되어 암반 내부 에서도 서로 교차할 것으로 예측할 수 있다(Fig. 7). 또한 본존불의 일부 지점에서 나타나는 균열대에는 토사가 충 전되어 있기도 하여 속도의 변수로 작용할 수 있다.

이를 종합적으로 고려할 때 구역으로 분리된 암반의 불 연속면에 대한 심도분석으로서의 초음파속도 측정은 적 합한 방법은 아닌 것으로 판단된다. 따라서 이 자료는 암 반사면 또는 본존불 구역에서 발생한 불연속면과 건전부 의 속도차이 및 균열부에서의 속도분포로 판단할 때 파 편화된 표면과 본존불 영역에서 균열에 따른 물성의 상 대적 차이를 분석하는 것으로 상당한 의미가 있다.

이를 반영하여 탐촉자 간의 거리는 $200 \mathrm{~mm}$ 로 접촉매 질은 엘라스토머 커버를 사용하였다. 또한 안산암의 보 정계수는 간접 및 직접측정법을 통한 음속비를 통해 1.64 로, 원산지 불명 및 피복생물로 인하여 직접측정이 어려 운 협시불 등 화강암은 8종의 화강암질암을 대상으로 산 출한 보정계수 1.48을 적용하였다(Lee et al., 2009; 2017; Jo and Lee, 2015). 초음파속도의 비교영역은 암반과 본 


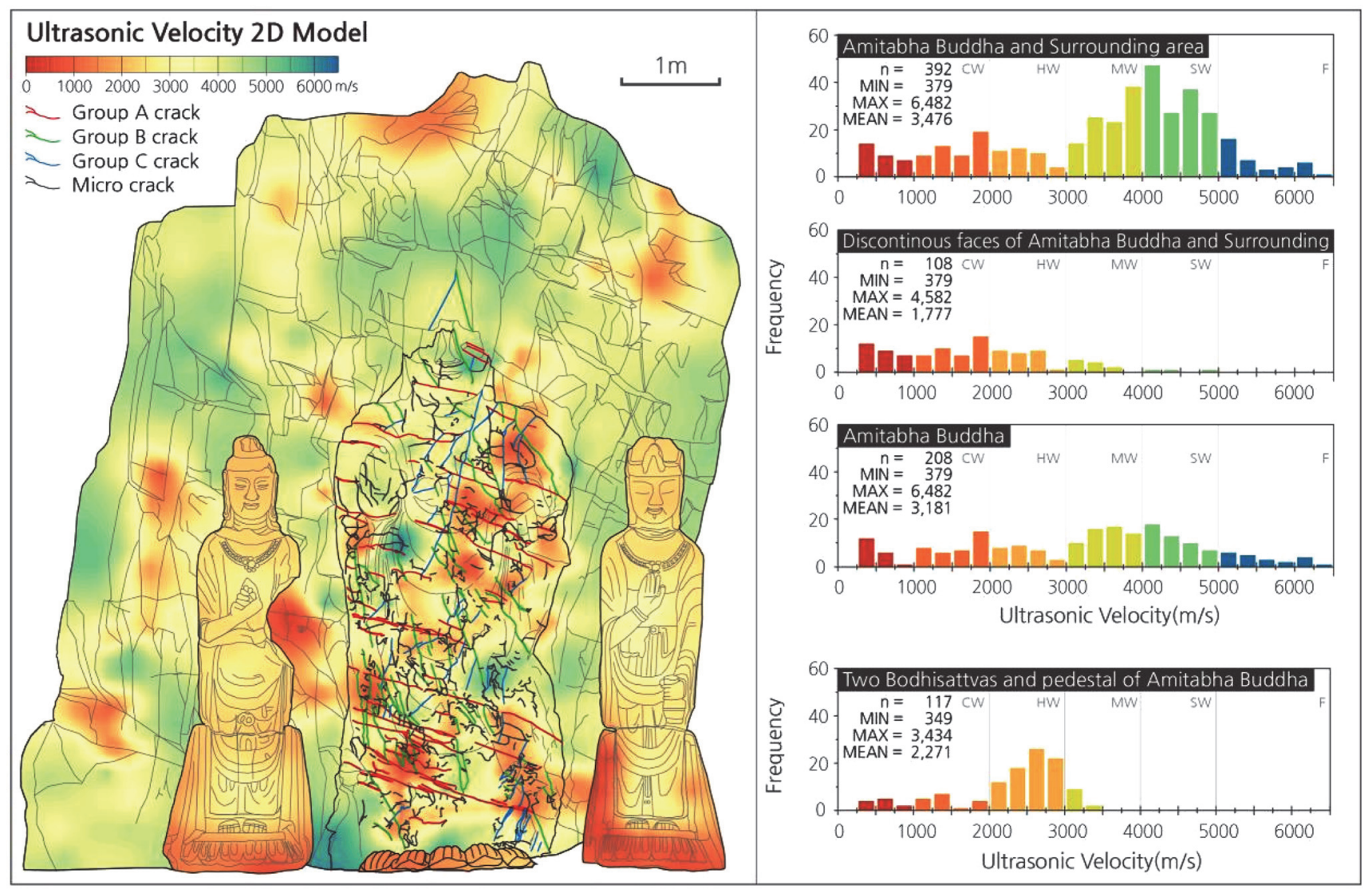

Fig. 7. Distribution map and histograms of ultrasonic velocity showing the $2 \mathrm{D}$ modeling on the host rock and the Buddha triad in Seoak-dong. Histograms are according to the standard by Iliev (1966). Cracks in various directions (A, B and C) on the Amitabha Buddha and surrounding area distributed into low grades (CW to MW), intensively. CW; completely weathered, HW; highly weathered, MW; moderately weathered, SW; slightly weathered, F; fresh.

존불을 포함한 안산암 및 불연속면 구역, 본존불 영역 및 협시불 부재로 나누어 검토하였다.

한편 초음파속도 범위에 따른 등급산정은 $\operatorname{Iliev(1966)}$ 가 제안한 다섯 등급으로 나누어 풍화등급별 속도분포를 평가하였다. 안산암으로 구성된 본존불과 암반의 모든 영 역에서 총 392 지점의 초음파를 측정하였으며, 속도는 $379 \sim 6,482$ (평균 3,476$) \mathrm{m} / \mathrm{s}$ 의 범위로 중간풍화등급 $(\mathrm{MW}$; moderately weathered)과 약한풍화등급(SW; slightely weathered)에서 가장 높은 비중으로 나타났다(Fig. 7).

이를 세분하면, 안산암질 기암반과 불연속면 분포영역 (108지점)의 초음파속도는 379 4,582(평균 1,777$) \mathrm{m} / \mathrm{s}$ 로 완전풍화등급 $(\mathrm{CW}$; completely weathered)에서 높은풍화 등급(HW; highly weathered)에 속하여, 대부분의 초음파 속도분포가 균열의 영향을 받은 것으로 나타났다(Fig. 7). 반면 본존불 영역(208지점)의 초음파 속도는 329 6,482 (평균 3,181$) \mathrm{m} / \mathrm{s}$ 로 모든 영역에서 비교적 고르게 분포하 는 특성을 보이나, 낮은 등급의 초음파속도는 불연속면 의 속도분포와 유사한 경향을 지시하였다.
화강암류로 조성된 협시불과 본존불의 대좌에서는 총 117 지점의 초음파속도를 획득하였다. 이 결과, 349 3,434 (평균 2,271 ) $\mathrm{m} / \mathrm{s}$ 의 범위로 나타나 균열이나 박리와 같은 물리적 손상이 적음에도 불구하고 $\mathrm{CW}$ 에서 $\mathrm{HW}$ 등 급을 보였다(Fig. 7). 특히 하등식물과 토양 피복층이 두 터운 협시불의 대좌 및 받침 부재에서 현저하게 낮은 물 성을 보였다.

\section{5. 표면 채색흔 분석}

연구대상 본존불과 협시불 표면에는 적색에서 적황색 을 띠는 채색흔적이 산재한다. 이는 표면손상에 따른 이 차적 생성물과 구분이 모호한 경우도 있어 보존처리 대 상 오염물과 보존해야할 원형을 구분할 필요가 있다. 따 라서 이를 명확하게 동정하기 위해 신선부를 대조군으로 삼아 안산암 신선부 5 지점, 알칼리 화강암 신선부 5 지점, 본존불의 적색 및 적황색 채색흔 6 지점, 대좌의 적황색 채석흔 3지점에 대하여 P-XRF로 분석하였다(Fig. 8).

본존불과 협시불의 신선부(1 10번)에서는 암종에 따 


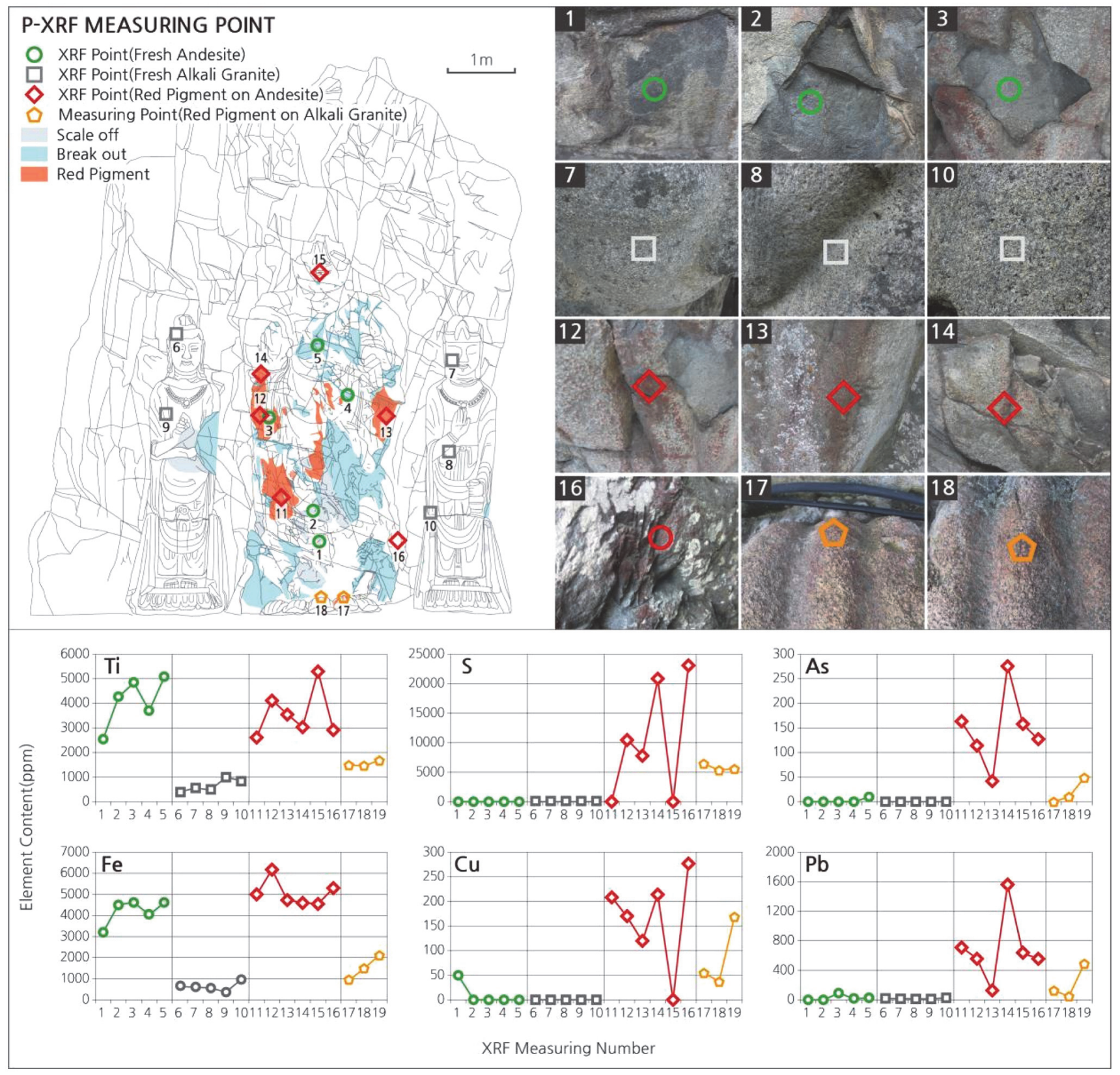

Fig. 8. Representative measuring points for P-XRF on traces of red pigments and fresh part of the Buddha triad in Seoak-dong. Contents of titanium and iron are higher fresh and traces of red pigments on andesite than the granites. Sulfur, arsenic, copper and lead were detected on almost traces of red pigments, but those elements were rare on the fresh rocks.

라 티타늄 $(\mathrm{Ti})$ 및 철 $(\mathrm{Fe})$ 의 함량에 차이가 두드러지게 발 생하는데, 채색흔(11 19번)에서도 이와 같은 경향이 뚜 렷하다. 반면 황 $(\mathrm{S})$, 비소 $(\mathrm{As})$, 구리 $(\mathrm{Cu})$ 및 납 $(\mathrm{Pb})$ 은 안 산암과 화강암에서 모두 검출량이 극히 낮거나 검출되지 않는다. 그러나 채색흔에서는 원소별로 최대 검출량이 황 $23,092 \mathrm{ppm}$, 비소 $277 \mathrm{ppm}$, 구리 $227 \mathrm{ppm}$ 및 납 1,666ppm 를 나타냈다.

또한 측정 부위마다 원소의 농도 편차가 심하여 채색 흔의 잔존량이 일정하지 않음을 보여주며, 이는 육안관
찰과도 일치하는 결과이다. 한편 안산암질 본존불 표면 의 채색흔에서는 비교적 원소 함량이 높았으며, 흑운모 화강암에서는 상대적으로 낮아 측정부위에 따른 표면의 요철도가 영향을 준 것으로 나타나나, 원소의 종류가 일 치하는 것으로 보아 인위적으로 칠한 적색 계통의 안료 로 판단하여 이들의 종류를 탐색하였다.

이미 보고된 바 있는 전통의 적색 무기안료로는 연단 $\left(\mathrm{Pb}_{3} \mathrm{O}_{4}\right)$, 주사 $(\mathrm{HgS})$, 웅황 $(\mathrm{AsS})$ 및 석간주 $\left(\mathrm{Fe}_{2} \mathrm{O}_{3}, \mathrm{Fe}^{+3} \mathrm{O}(\mathrm{OH})\right)$ 가 있다. 연구대상 본존불의 적색계통 채색 안료에서 검 
출된 성분을 바탕으로 발색 재료로 가능한 광물을 검토 하면 적동 $\left(\mathrm{Cu}_{2} \mathrm{O}\right)$ 과 밀타승 $(\mathrm{PbO})$ 등도 포함된다 $(\mathrm{Kim}$ and Lee, 2019; National Research Institution of Cultural Heritage, 2017).

웅황을 구성하는 비소와 황은 적황색 채색흔에서 공통 적으로 검출되지만 이외의 다른 원소들은 단일 안료의 도포 흔적으로 보기 어렵다. 그러나 본존불 법의 박락부 채색흔에는 다양한 성분의 적색 계통의 안료를 지속적으 로 덧칠한 흔적이 있다. 따라서 P-XRF로 산소 $(\mathrm{O})$ 의 분 석이 어려운 것을 감안하면 가장 특징적으로 검출되는 납을 포함한 연단 $\left(\mathrm{Pb}_{3} \mathrm{O}_{4}\right)$ 이 적색 안료의 주성분 원소로 판단된다.

이와 함께 원료로 사용한 것으로 추정되는 적황색 부 분의 비소와 황은 웅황(AsS)을 안료로 추정할 수 있으며 이들이 연단과 함께 용해 및 잔류하여 검출된 것으로 보 인다. 그러나 미량 검출되는 구리는 안료흔이라기 보다 는 본존불의 균열대를 고정하기 위해 여러 곳에 사용한 청동못의 산화잔류물로 해석하였다.

\section{4. 결 언}

신라인들은 서라벌의 서쪽에 있는 선도산을 신성한 산 으로 여겨 서악이라 했으며, 이 산의 남동쪽 정상부에 서 악동 마애여래삼존입상을 조성하였다. 본존불인 아미타 불상은 선도산의 기반암인 백악기의 안산암에 새긴 마애 불로 모암의 구조적 불연속면에 의해 물리적 손상이 심 한 상태이다. 또한 수목이 우거진 산중에 입지하여 본존 불의 표면은 조류와 지의류 및 선태류의 착생에 의한 생 물학적 풍화도 가중되어 있는 등, 복합적인 손상메커니 즘을 잘 보여주는 사례이다.

그러나 본존불의 대좌는 흑운모 화강암으로 조성하였 고, 좌우의 두 협시불도 불신은 알칼리 화강암을, 대좌와 받침은 홍장석 화강암을 사용하였다. 이들 화강암질 암 석은 모두 선도산 일대에 분포하는 암석이 아닌 별도로 유입된 석재로서 조성과 경위는 잘 알려져 있지 않다. 전 체적으로 삼존입상의 위계와 배치 및 구도에 따라 다양 한 색상과 질감의 석재를 사용함으로서 불상의 위엄과 대비효과를 의도한 것으로 볼 수 있을 것이다.

복잡한 시스템을 갖는 불연속면이 발달하여 불안정한 상태인 본존불과 기반암은 부분적으로 암면의 평면파괴 와 전도파괴 및 쐐기파괴의 가능성이 높은 것으로 예측 되었다. 암반의 상부는 파괴유형이 다양하여 암편의 탈 락이 발생할 수 있어 좌우의 협시불에 물리적 충격을 줄 수도 있을 것으로 예상된다. 또한 상부의 하중과 토압 및 본존불 암반의 식생에 따른 근압 등에 의해 암편의 분리
와 이격이 늘어날 수 있으며, 특히 강수와 동결융해작용 에 의해 큰 손상을 당할 수 있어 적극적인 보존관리가 필요한 상태이다.

본존불과 두 협시불의 구성암석에 대한 초음파 물성 측 정 결과, 안산암질 본존불의 물리적 풍화정도는 $\mathrm{CW}$ 에서 $\mathrm{SW}$ 등급까지 고르게 분포하고 있으며, 비교적 높은 풍 화도를 지시하는 $\mathrm{CW}$ 와 $\mathrm{HW}$ 등급은 절리와 미세균열 및 박리의 분포와 일치하였다. 한편 두 협시불을 구성하는 화강암 석재는 전반적으로 초음파속도가 낮고, 특히 대 좌 및 받침에서 두드러지게 물성이 저하된 것으로 나타났다.

본존불의 입술과 법의에서 관찰되는 적색 또는 적황색 채색흔적은 황과 비소 및 납이 주성분으로 안료의 농도 와 조암광물의 입도에 따른 요철정도에 의해 농도차를 보이며 검출되었다. 이 채색흔은 전통 적색 및 황색 안 료의 대표적인 조성으로 보아 연단과 웅황의 가능성이 매우 높은 것으로 해석하였다. 그러나 법의에 나타난 박 락부의 채색흔으로 보아 오랜 기간 다양한 성분의 적색 및 황색 안료를 지속적으로 덧칠하여 불안의 입술과 법 의 및 대좌를 장식한 것으로 판단된다.

이와 같이 서악동 마애여래삼존입상은 다양한 요인과 자연적 풍화에 따라 심한 손상을 입었다. 특히 본존불의 암면은 세편화와 수목의 생장에 따라 부분적으로 사면파 괴의 우려도 있다. 또한 암반의 불연속면과 절리의 이격 은 유수와 토사 및 오염물의 이동통로가 되어 손상을 가 속시킬 수 있다. 따라서 본존불 상부의 지질공학적 보강 과 식생제어 및 토사의 정비와 배수체계 등 적극적인 보 존관리가 필요하며, 암반사면의 장기적 거동특성 분석을 위한 지속적인 모니터링이 요구된다.

\section{References}

Barton, N. (1973) Review of a new shear strength criterion for rock joints. Engineering Geology, v.7, p.287-332.

Barton, N. (1976) The shear strength of rock and rock joints. International Journal of Rock Mechanics and Mining Science \& Geomechanics Abstract, v.13(9), p.255-279.

Crispim, C.A. and Gaylarde, C.C. (2004) Cyanobacteria and biodeterioration of cultural heritage: a review. Microbial Ecology, v.49, p.1-9.

Fitzner, B. and Heinrichs, K. (2001) Damage diagnosis on stone monuments - Weathering forms, damage categories and damage indices. Stone Weathering and Atmospheric Pollution Network (SWAPNET), Decin, May, p.7-11, p.11-56.

Fitzner, B., Heinrichs, K. and La Bouchardiere, D. (2003) Weathering damage on Pharaonic sandstone monuments in Luxor-Egypt. Building and Environment, v.38(9-10), p.1089-1103.

Iliev, I.G. (1966) An attempt to estimate the degree of weathering of intrusive rocks from their physical-mechanical properties. 
Proceedings of the International Congress on Rock Mechanics, v.1, p.109-114.

Jin, H.S. (1962) Bodhisattva of rock-carved stone Buddha in Seoakri, Gyeongju. Art Reference, v.6, p.15-18. (in Korean)

Jo, Y.H. and Lee, C.H. (2011) Making method of deterioration map and evaluation techniques of surface and three-dimensional deterioration rate for stone cultural heritage. Journal of Conservation Science, v.27, p.251-260. (in Korean with English abstract)

Jo, Y.H. and Lee, C.H. (2014a) Quantitative modeling and mapping of blistering zone of the Magoksa temple stone pagoda (13th century, Republic of Korea) by graduated heating thermography. Infrared Physics and Technology, v.65, p.43-50.

Jo, Y.H. and Lee, C.H. (2014b) Quantitative modeling of blistering zones by active thermography for deterioration-evaluation of stone monuments. Journal of Cultural Heritage, v.15, p.621-627.

Jo, Y.H. and Lee, C.H. (2014c) Establishment of ultrasonic measurement method for stone cultural heritage considering water content and anisotropy. Journal of Conservation Science, v.30(4), p.467-480. (in Korean with English abstract)

Jo, Y.H. and Lee, C.H. (2015) A study on selection of ultrasonic transducer and contact material for surface irregularities of stone cultural heritage. Journal of Conservation Science, v.31(3), p.267-278. (in Korean with English abstract)

Kim, J.S. and Lee, C.H. (2019) Interpretation of coloring technique and pigment analysis for King Sejo's palanquin in Gongju Magoksa temple, Korea. Journal of Conservation Science, v.35(5), p.403-415. (in Korean with English abstract)

Kim, S.D., Yi, J.E., Lee, D.S. and Lee, C.H. (2011) Homogeneity investigation of replace stone for restoration of the Mireuksaji stone pagoda in Iksan, Korea. Journal of Conservation Science, v.27(2), p.211-222. (in Korean with English abstract)

Lee, C.H. and Ariki, N., 2019, Evaluation of nondestructive diagnosis and material characteristics of stone lantern at Damyang Gaeseonsaji temple site in Korea. Journal of Conservation Science, v.35(4), p.279-293.

Lee, C.H., Choi, S.W., Han, K.S. and Won, K.S. (2001) Approach to conservation sciences and mechanical deteriorations of the Seoagdong standing triple Buddha, Gyeongju, Korea. Journal of the Geological Society of Korea, v.37, p.611-627. (in Korean with English abstract)

Lee, C.H., Chun, Y.G., Jo, Y.H. and Suh, M. (2012) Evaluation of slope stability and deterioration degree for Bangudae petroglyphs in Ulsan, Korea. Journal of Conservation Science, v.28(2), p.153164. (in Korean with English abstract)

Lee, C.H., Kim, M.Y., Jo, Y.H. and Lee, M.S. (2010) Conservation treatment based on material characteristics, provenance presumption and deterioration diagnosis of the Seven-storied Jungwon Tappyeongri stone pagoda, Chungju, Korea. Korean Journal of Cultural Heritage Studies, v.43(3), p.4-25. (in Korean with English abstract)

Lee, C.H., Kim, Y.T. and Lee, M.S. (2007) Provenance presumption for rock properties of the five storied stone pagoda in the Jeongrimsaji temple site, Buyeo, Korea. Journal of the Geological Society of Korea, v.43, p.183-196. (in Korean with English abstract)

Lee, C.H., Lee, M.S., Kim, Y.T. and Kim, J.Y., 2006, Deterioration assessment and conservation of a heavily degraded Korean stone Buddha from the 9th Century. Studies in Conservation, v.51, p.305-316.

Lee, C.H., Jo, Y.H. and Kim, J. (2011) Damage evaluation and conservation treatment of the tenth century Korean rock-carved Buddha statues. Environmental Earth Science, v.64, p.1-14.

Lee, C.H., Jo, Y.H. and Chun, Y.G. (2009) Establishment of ultrasonic measurement and correlations of direct-indirect method for weathering evaluation of stone cultural heritage. Conservation Science, v.25(3), p.233-244. (in Korean with English abstract)

Lee, C.H. and Jo, Y.H. (2017) Correlation and correction factor between direct and indirect methods for the ultrasonic measurement of stone samples. Environmental Earth Science, v.76, p.477-489.

Lee, C.H., Shin, H.C. and Han D.R. (2017) Ultrasonic properties on building stones, characteristics of structural deformation and conservation states of the sanctuary in Wat Phou temple of Champasak, Lao PDR. Journal of Conservation Science, v.33(6), p.399-416. (in Korean with English abstract)

Ministry of Land, Infrastructure and Transport of National Geographic Information Institute (2020) https://www.ngii.go.kr/ (in Korean)

Moon, M.D. (1969) Statue of the Buddha in Gyeongju Seoak : About Seondosan Mt. and Dudae-ri rock-carved standing Buddha triad. Art and Archaeology, v. 104, p.16-17. (in Korean)

National Geographic Information Institute (2020) The Origin of Korean Geographical Names. p.277. (in Korean)

National Research Institution of Cultural Heritage (2017) Investigation and Analysis of Traditional Pigment Minerals of Dancheong. p.15, 84. (in Korean)

National Research Institute of Cultural Heritage (2019) Periodic Investigation of National Designated Architectural Heritage. The Rock-carved Standing Buddha Triad in Gyeongju Seoak-dong, v.6, p.132-149. (in Korean)

Odonne, F., Lezin, C., Massonnat, G. and Escadeillas, G. (2007) The relationship between joint aperture, spacing distribution, vertical dimension and carbonate stratification: an example from the Kimmeridgian limestones of Pointe-du-Chay (France). Journal of Structural Geology, v.29, p.746-758.

Rhim, H.C., Kim, Y.S., Woo, S.K. and Song, Y.C. (2002) Measurement of crack depth located under steel reinforcement in reinforced concrete specimens using ultrasonic method. Journal of the Korea Institute for Structural Maintenance Inspection, v.6, p.181188. (in Korean with English abstract)

Varnes, D.J. (1978) Slope movement types and processes. In Schuster, R.L. and Krizek, R.J. (eds.) In Special Report 176, Landslides: Analysis and Control, National Academy of Science, Washington DC, p.11-33.

Yang, H., Lee, C.H. and Jo, Y.H. (2020) Stability and damage evaluation of the Buddha Triad and 16 Rock-carved Arhat Statues at Seongbulsa temple in Cheonan, Korea. Korean Journal of Cultural Heritage Studies, v.53(4), p.78-99. (in Korean with English abstract) 